\title{
THE CONCEPT OF PATRIOTISM AS PERCEIVED BY TEENAGERS IN LATVIA
}

\author{
MARINA MARCHENOKA \\ Rezekne Academy of Technologies, \\ Faculty of Education, Language and Design \\ Atbrivosanas aleja 115, Rezekne, LV-4601, Latvia \\ E-mail adress: marina-mar4enoka@inbox.lv \\ ORCID ID: https://orcid.org/0000-0002-0922-636X
}

\begin{abstract}
Aim. The aim of the research is a theoretical investigation of the problem of patriotism and its urgency, the empirical research for defining the level of perception of the concept "patriotism" by teenagers in Latvia.

Methodology of the research. The theoretical basis of the research includes a theoretical analysis of various conceptual approaches to understanding of the phenomenon of patriotism in the philosophical aspect, as well as official documents of the European Union and the Republic of Latvia. The Empirical methods of the research: methods of data acquisition: a questionnaire (anonymous); methods of data processing and analysis: quantitative data processing with methods of mathematical analysis of statistical data and forecasting analytical methods in data processing software Microsoft Office Excel 2010 and SPSS (Statistical Package for the Social Sciences) 18.0 version; qualitative data processing (analysis of the content, coding, and processing of the acquired data); interpretation of quantitative and qualitative.

Results. The theoretical analysis makes it possible to conclude that the main idea of the concept patriotism consists of considering it as one of the highest values of the individual and is the basis of life orientations, defining the strategy of the individual's development, harmonisation of the society and the state. The main approaches for investigation of the concept of patriotism are: sensitively emotional, active and publicly national.
\end{abstract}

Key words: patriotism, teenagers, society, values, Motherland

\section{INTRODUCTION}

"Ask not what your country can do for you ask what you can do for your country"

(John F. Kennedy)

uccessive generations, especially under conditions of globalisation, polyculSture, and integration processes in circumstances of socially economic transformation of the society and state lead to the collapse of the system of traditio- 
nal values and alteration of the content and meaning of numerous phenomena and concepts. The given processes in modern society are eroding such socially moral and value landmarks as respect and love of the Motherland, self-sacrifice, and patriotism, wish and ability to work for the sake of the country, aspiration to be useful for it. The sense of responsibility and duty to parents, family, co-workers, society, Motherlands has been largely lost. Prevailing landmarks in the hierarchy of values for the modern generation are financial welfare, entertainment (having a pleasant time, absence of obligations), and freedom (independence in judgements and actions, self-determination). Unfortunately, such important personal qualities as responsibility (sense of duty, keeping one's word), tolerance (to other people's opinions and beliefs, ability to accept other people's opinions, respect for other people's taste, customs and habits, tolerance towards other people's faults and errors), other people's happiness (development and advancement of other people and the entire humanity) are losing their value (Marchenoka, 2016).

Personal responsibility, sense of belonging, and affiliation to the events happening around define the individual's attitude to people around him, to society, therefore define the individual's attitude to the future of his country. Many teenagers are not proud of their country, of its achievements. As a result, the concept of patriotism is perceived as "an old-fashioned and needless quality for a modern person" (Berger, 2011, p. 24). Patriotism appears in all spheres of living activity of people (communication, studies, work), therefore negative factors, which are related to this phenomenon, emerge in all spheres of life. It causes destruction of communication and interaction, decrease of the sense of responsibility, absence of socially important life goals, resulting in the generation's reorientation in concepts and values.

\section{Theoretical Framework}

The topicality of the phenomenon of patriotism, which is one of "the fundamental values of human civilisation" (Konfucij, 2014, p.7) can be viewed in the beginnings of its investigation, as it was already examined in ancient authors' works. Aristotle, Plato, Democritus, Socrates, Cicero, Confucius et alia considered the issue of love of the motherland as the highest value and examined ideas of patriotism as the basis for ethical upbringing of citizens and prosperity of society. Thus, the Greek philosopher Plato asserted that "a patriot is not just a warrior, it is a person, who applies his abilities for improvement of the society's life, its citizens, for achieving stability aiming at elevating of the state (Platon, 2016). Aristotle derived his formula: "a person is a societal being, but the highest level of virtue are activities for the sake of fellow citizens, for the love of the motherland. This virtue is not acquired through studies and persuasion, but from a habit for benevolent acts, which is established in childhood and fastened by favourable surroundings, where the person is being raised" (Aristotle, 2009).

French philosophers Jean-Jacques Rousseau, Diderot, and Claude Adrien Helvetius adhered to the same point of view. In J. -J. Rousseau's opinion, “start- 
ing from the age of 15-22 sound senses should be developed: duty, civil virtue, patriotism and compassion for people" (Basov, Basova, Kravcenko, 2018, p. 92). Humanism became the main idea of the époque of Renaissance, and it was based on the understanding of the necessity of raising a person-citizen and patriot (E. Roterodamus, F. Rabelais, M. Montaigneet alia). Development of national self-consciousness, which started during the Renaissance in many countries, also actualised the problem of a high-minded person-citizen. The main aim of bringing a person up becomes development of a conscious civic position. Moral upbringing in C. Fourier's, Thomas More's, H. Saint-Simon's judgments is also regarded in interaction with the formation of civic qualities in a person, the sense of duty for service to the interests of the society.

In concepts of philosophers of $17^{\text {th }}-18^{\text {th }}$ centuries the problem of civic, patriotic and universal upbringing is developed (G. Hegel, C. Montesquieu, J. Locke, etc.), where patriotism is considered as a demonstration of the sense of national pride of the country. Thus, Charles Louis de Montesquieu believed that global welfare is based on the love of the law and the Motherland. "The love for the Motherland can be developed in children, if their fathers have it" (Montesquieu, 2008 , p. 27). In general, the concept "patriot" was used till the end of the $17^{\text {th }}$ - the beginning of the $18^{\text {th }}$ century in relation to those people who were concerned about the good and manifesting absolute fidelity to the Motherland without any individual benefits. At this stage the idea of state patriotism was born because philosophers regarded the state on the whole as an object of patriotic senses. Thus, English poet George Gordon Byron believed, that "the person, who does not love his country, cannot love anything" (Kurginjan, 1958, p.117).

When examining this phenomenon in the $20^{\text {th }}$ century, it is appropriate to remember American president Theodore Roosevelt's citation concerning his attitude to patriotism, which was not only expressed in public but also was used in practice, when rendering important political decisions, contributing to the development of this quality in inhabitants of the USA. He used to say that "readiness to live your life for the country is more important than giving your life for it" (Tomas, 2013, p.1). The American philosopher and psychologist Carrol Izard (2013) also considered patriotism as a high socially moral quality of a person.

The principle of citizens' responsibility to the society was fixed in the Universal Declaration of Human Rights, which was adopted by the General Assembly of the UN (1948) - its Article 29 stipulated that "Everyone has duties to the community in which alone the free and full development of his personality is possible" (Susan Muaddi Darraj, 2010, p.76).

It is necessary to notice that investigation of the problem of patriotism has become more active in the $21^{\text {st }}$ century. Numerous documents highlight the importance of the civic commitment of the growing generation. Thus, the EU Strategy for Youth - Investing and Empowering emphasises the significance of youngsters' civic involvement: "Europe's future depends on its youth, youth is one of the EU priorities in the social aspect and youngsters should use their potential in a better way" (Commission of the European communities, 2009, p. 8). It confirms the fact that civil active youth is the basis for the sustainable 
development of the state. In addition, the number of youngsters is growing in the world - according to the data of the United Nations International Children's Fund youngsters aged from 15 to 25 make up one fifth of the population of the world (UNICEF, 2012).

The preamble to the main law of the Latvian Republic - the Constitution emphasises the aspect of citizens' responsibility: "Each individual takes care of oneself, one's relatives and the common good of society by acting responsibly towards other people, future generations, the environment and nature" (Berzinsš, 2014, p. 1). In the Guidelines on national identity, civil society and integration policy (2012-2018) it is written that strengthening of the national and civil identity and understanding of the complex of the Latvian society's values is needed and the task is defined: "to promote individual responsibility for national development, as well as to teach every individual civic participation skills, knowledge, attitudes and values (Ēltere, 2011, p.12).

In its turn, the National Development Plan of Latvia for 2014-2020 also highlights the importance of upbringing a citizen for the achievement of the aims: "to promote people's sense of belonging, civic consciousness and pride in their country and nation" (Dombrovskis, 2012, p.49).

The topicality of the given problem was also underlined in the Guidelines for the Development of Education for 2014-2020 in Latvia. The document for planning the policy in the field of education calls on strengthening the civic consciousness of students, skills of public involvement and patriotism, ensure youth's involvement into common national activities, to promote the improvement of cultural education and creativity development, as well as the acquisition of basic requirements indicated in the standard of education (Āboltina, 2014).

"Every pupil is a member of the society, a subject of life, who can contribute to the development of his country, or on the contrary - can do nothing for it. Following Latvia's accession to the EU, its youngsters have the opportunity to study and work abroad. They are little concerned about the future of their native town, country, that is why the problem of responsibility of every person to his or her country has become so topical nowadays. Changes in individual development in youngsters depend on the aims and on the way how their attitude to the native region and state is being stimulated. It is necessary to create an interest in and respect for the native place, the ability to feel, and work for it. The patriotic attitude to the native region contributes to the strengthening and development of the country" - this is the way how researcher of patriotic education in Inara Dunska defines the understanding of modern patriotism Latvia (Butulis, 2012, p.1).

Latvian historian Ilgvars Butulis (2012, p.1), when speaking about patriotism, gives a laconic definition: "it is love to the motherland, respect to its people, land, common values and also state". The professor notes that patriotism in Latvia is influenced by a range of problems: "the level of knowledge of national history, safeguarding of national values in the entire Latvia, as well as the pressure of common values of the European Union. The patriotic attitude on behalf of the state is also far from perfect" (Butulis, 2012, p.1). Latvian con- 
ductor Janis Erenstreits believes that "patriotism cannot be taught; it must be a profound feeling in a person" (Butulis, 2012, p.1).

Thus, the theoretical analysis makes it possible to conclude that the main idea of the given phenomenon is the consideration of it as one of the highest personal values, promoting the development of responsibility and sense of duty for service to the society and development of the country as a whole. Basic approaches in the investigation of the concept of patriotism are:

- sensitively emotional, defining patriotism through the sense of love for the native region, paternal home and the Motherland as a whole;

- active, motivating the person for active actions for the sake of the Motherland and developing the striving towards being useful;

- publicly national, where the object of patriotism is the state developing the patriotic consciousness in the society.

Therefore, it is possible to affirm that patriotism, which is regarded as a socially moral phenomenon, is the basis of life orientations, defining the strategy for the development of the individual, society and state.

\section{EMPIRICAL RESEARCH}

Participants of the empirical research: pupils of the $8^{\text {th }}-9^{\text {th }}$ grade (in total 373 respondents) of various institutions of general education in Latvia.

Table 1.

The basis of the empirical research

$\begin{array}{ccccc} & \text { Frequency } & \text { Percent } & \text { Valid Percent } & \begin{array}{c}\text { Cumulative } \\ \text { Percent }\end{array} \\ \begin{array}{c}\text { Valid } 8^{\text {th }} \\ \text { grade }\end{array} & 197 & 52.8 & 52.8 & 52.8 \\ \begin{array}{c}9^{\text {th }} \\ \text { grade }\end{array} & 176 & 47.2 & 47.2 & 47.2 \\ \begin{array}{c}\text { Total } \\ \text { Author sesearch }\end{array} & 373 & 100.0 & 100.0 & 100.0\end{array}$

For achieving the aim of the research, the author developed a questionnaire, which included three units of questions:

- a unit directed towards investigation of the particular and general comprehension of patriotism (a sensitively emotional approach);

- a unit aiming at the investigation of patriotism where the object is the state, as well as the state's activity in the upbringing of patriotic values ( $a$ publicly national and active approach);

- a unit directed towards investigation of personal qualities of a patriot/ an antipatriot, as well as the activity, motivating the person for active actions for the sake of the Motherland and developing aspiration for being useful (a personal and active approach). 
The questionnaire includes both closed questions with answer variants, as well as open questions requiring more sapid explanation.

\section{RESULTS}

The first unit of questions of the questionnaire discovers the particular and general understanding of the concept of patriotism. For defining of the individual conception 13 short variants were offered.

\section{Table 2.}

Individual understanding of patriotism by teenagers in Latvia

No. Choose, in your opinion, the most appropriate definition $\quad \%$

$$
\text { of patriotism }
$$

1 aspiration for social equity; $\quad 0$

2 love of the national culture; $\quad 2$

3 love of the family and relatives; $\quad 19$

4 communal way of life; $\quad 0$

5 aspiration for safe global peace; $\quad 0$

6 love of the Motherland; $4 \mathbf{4 1}$

7 love of the native town, village, home; 5

8 the religion that I manifest; $\quad \mathbf{1}$

9 revival of traditions of my country; 4

10 love of the entire humanity, humanism; 0

11 respect for the Motherland, pride for own country; 9

12 love of the people of own country; $\quad 6$

13 under conditions of globalisation patriotism is losing its meaning. 13

\begin{tabular}{|c|c|c|c|c|c|c|c|c|c|c|c|c|c|c|}
\hline & \multicolumn{13}{|c|}{ Individual understanding of patriotism } & \multirow{2}{*}{$\begin{array}{l}\text { To- } \\
\text { tal }\end{array}$} \\
\hline & 1 & 2 & 3 & 4 & 5 & 6 & 7 & 8 & 9 & 10 & 11 & 12 & 13 & \\
\hline $\begin{array}{l}\text { Frequen- } \\
\text { cy }\end{array}$ & 0 & 7 & 71 & 0 & 0 & 153 & 19 & 4 & 15 & 0 & 34 & 22 & 48 & 373 \\
\hline Percent & 0 & 2,1 & 18,9 & 0 & 0 & 41,4 & 4,6 & 1,3 & 4,3 & 0 & 9,2 & 5,6 & 12,6 & 100 \\
\hline $\begin{array}{l}\text { Valid } \\
\text { Percent }\end{array}$ & 0 & 2,1 & 18,9 & 0 & 0 & 41,4 & 4,6 & 1,3 & 4,3 & 0 & 9,2 & 5,6 & 12,6 & 100 \\
\hline $\begin{array}{l}\text { Cumula- } \\
\text { tive } \\
\text { Percent }\end{array}$ & 0 & 2 & 21 & 0 & 0 & 62,4 & 67 & 68,3 & 72,6 & 0 & 81,8 & 87,4 & 100 & 100 \\
\hline Total & & & & & & & & & & & & & & 373 \\
\hline
\end{tabular}

The sense of love for the Motherland can be defined as a sensitively emotional approach to the given definition. Given such a definition, the basis of the content of patriotism is the emotional attitude to the native region, parental home, and the Motherland as a whole. The word Motherland means "the place, 
where I was born, home, childhood, family and mother". It should be noted that such definitions of patriotism as "aspiration for social equity", "love towards the entire humanity, humanism", "aspiration to safe global peace", "communal way of life" are not important for teenagers.

Amongst the extended definitions of the given concept the following citation prevails (59\%): "Patriotism is a moral and political principle, a social sense, consisting of love for the Motherland, pride for its past and present, readiness to subordinate own interests to interests of the state" (Kont-Sponvilj, 2012). It is interesting that for numerous respondents (14\%) the definition of patriotism is expressed in "separation of oneself and of the state from other countries and nations", which is in contradiction with the process of globalisation in the modern world. It is also necessary to remark that teenagers consider patriotism in "the possibility to say about the state everything that a person thinks and not only good words" (17\%). A small percentage of respondents (7\%) define patriotism as "love for the Motherland, resulting from the feeling of solidarity of the state's citizens' interests".

\section{Table 3.}

General understanding of patriotism by teenagers in Latvia

No. Choose, in your opinion, the most appropriate definition of patriotism $\%$

1 Patriotism is the possibility to say about the state everything that a person thinks, and not only good words;

2 Patriotism is love for the Motherland, resulting from the feeling of solidarity of the state's citizens' interests;

3 Patriotism is a moral and political principle, a social sense, consisting of love for the Motherland, pride for its past and present, readiness to subordinate own interests to interests of the state;

4 Patriotism, where the main component is separation of oneself and of the state from other countries and nations;

5 Patriotism is fidelity and love towards own motherland and people;

6 Other

Choose, in your opinion, the most appropriate

\section{definition of patriotism}

$\begin{array}{cccccccc} & \mathbf{1} & \mathbf{2} & \mathbf{3} & \mathbf{4} & \mathbf{5} & \mathbf{6} & \\ \text { Frequency } & 67 & 26 & 213 & 56 & 11 & 0 & \mathbf{3 7 3} \\ \text { Percent } & 16,7 & 7,2 & 58,8 & 13,8 & 3,5 & 0 & \mathbf{1 0 0} \\ \text { Valid Percent } & 16,7 & 7,2 & 58,8 & 13,8 & 3,5 & 0 & \mathbf{1 0 0} \\ \text { Cumulative } & 17,6 & 23,9 & 82,7 & 96,5 & 100 & 100 & \mathbf{1 0 0} \\ \quad \begin{array}{c}\text { Percent } \\ \text { Total }\end{array} & & & & & & & \\ \end{array}$

Source: Author`s research

The question "How is the real patriotism manifested?" was answered as follows: 


\section{Table 4.}

Manifestation of patriotism by teenagers in Latvia

In your opinion, how is real patriotism manifested?

1 in conversations and talks on patriotic topics with friends;

2 in voting at elections

3 in participation in the work of patriotic organisations 1

4 in celebrating historical events and anniversaries 26

5 in constructive critique of drawbacks in the country 21

$\mathbf{6}$ in responsible studying and work with full commitment in the specialty $\mathbf{1 5}$

7 in strengthening the family and in upbringing children in the spirit of patriotism $\mathbf{1}$

8 other

\begin{tabular}{ccccccccccr} 
& \multicolumn{1}{c}{ How is the real patriotism manifested? } & & Total \\
& 1 & 2 & 3 & 4 & 5 & 6 & 7 & 8 & \\
Frequency & 4 & 131 & 4 & 97 & 78 & 56 & 4 & 0 & 373 \\
Percent & 1,4 & 34,7 & 1,3 & 26,3 & 20,9 & 14,6 & 0,8 & 0 & 100 \\
Valid Percent & 1,4 & 34,7 & 1,3 & 26,3 & 20,9 & 14,6 & 0,8 & 0 & 100 \\
Cumulative & 1,4 & 36,1 & 37,4 & 63,7 & 84,6 & 99,2 & 100 & 100 & 100 \\
$\quad$ Percent & & & & & & & & & \\
Total & & & & & & & & & 373
\end{tabular}

Source: Author's research

The manifestation of patriotism is an essential issue, which consists of the teenager's wish to reform his country, to do something to make life better, to undertake actions for making the country stronger, etc. Thus, it seems that the dominating answer would be "responsible studies or work with full commitment in the specialty". But this indicator received only $15 \%$ of the respondents' answers, preferring politicians and political parties of the state, whom teenagers render the possibility to solve main tasks/ problems in the country with help of voting at elections (35\%). In addition, teenagers consider the constructive critique of drawbacks in the country (21\%) to be a manifestation of patriotism.

In the next unit, the object of patriotism is the state. When answering the question "Are you proud of your country?", 57\% of the respondents gave a positive reply. Examples are: "Song and dance festivals", " the 100 th anniversary of Latvia's independence", "sport achievements - the Latvian national team's participation in the Ice Hockey World Championship", "soccer", "volleyball", "interesting people living in our country", "veterans of the Great Patriotic War". Nevertheless, 34\% of the respondents do not feel pride for their country- this is rather a high indicator. Reasons are: "there is no work", "my grandmother has got a little pension", "the level of life differs from the one in other countries", "low salaries", "everything is expensive", "when I watch the news", "Latvia has stopped production of anything", "when millions are wasted for fireworks, but this money could be spent for something more important", etc. It is necessary to note that there was also such an answer: "I don't feel ashamed for my country, because it isn't guilty for the government's and deputies' lack of competence". $29 \%$ of the respondents are willing to emigrate from the country: $22 \%$ of them want to work 
abroad after graduation, 7\% would like to study abroad. 9\% will not leave Latvia under any circumstances.

Table 5.

Are you proud of your country?

$\begin{array}{ccccc} & \text { Frequency } & \text { Percent } & \begin{array}{c}\text { Valid } \\ \text { Percent }\end{array} & \begin{array}{c}\text { Cumulative } \\ \text { Percent }\end{array} \\ \text { Valid Yes } & 214 & 56,7 & 56,7 & 56,7 \\ \text { No } & 127 & 33,9 & 33,9 & 90,6 \\ \text { It's difficult to say } & 14 & 4,3 & 4,3 & 94,9 \\ \text { I haven't thought about it } & 18 & 5,1 & 5,1 & 100 \\ \text { Total } & 373 & 100 & 100 & \end{array}$

Source: Author`s research

The question "What must be done by the state for upbringing patriotic values?" received the following answers:

\section{Table 6.}

What must be done by the state for upbringing patriotic values?

No. What must be done by the state for raising patriotic values? $\quad \%$

1 development of the sense of patriotism already in the pre-school age; $\mathbf{1}$

2 development of the sense of patriotism in primary school; 3

3 promotion of emergence of a larger amount of patriotic topics in the $\mathbf{1}$ mass media;

4 creation of patriotic hobby groups, clubs, organisations; $\quad 7$

5 organisation of military patriotic games; $\quad \mathbf{4}$

6 creation and demonstration of a larger amount of patriotic films, $\mathbf{0}$ dissemination of patriotic fiction literature;

7 improvement of living conditions (creation of work places, salary $\mathbf{6 0}$ increase, housing available);

8 improvement of the image of the country (increasing Latvia's role $\mathbf{1 7}$ significance on the international level);

9 organisation of leisure time for youngsters; $\quad 6$

10 personal example 1

11 other 0

\begin{tabular}{|c|c|c|c|c|c|c|c|c|c|c|c|c|}
\hline & \multicolumn{11}{|c|}{ What must be done by the state for upbringing patriotic values? } & Total \\
\hline & 1 & 2 & 3 & 4 & 5 & 6 & 7 & 8 & 9 & 10 & 11 & \\
\hline Frequency & 4 & 11 & 4 & 26 & 15 & 0 & 224 & 63 & 22 & 4 & 0 & 373 \\
\hline Percent & 0,8 & 3,1 & 1,2 & 7,3 & 4,2 & 0 & 60,3 & 16,7 & 5,8 & 0,6 & 0 & 100 \\
\hline Valid Percent & 0,8 & 3,1 & 1,2 & 7,3 & 4,2 & 0 & 60,3 & 16,7 & 5,8 & 0,6 & 0 & 100 \\
\hline $\begin{array}{l}\text { Cumulative } \\
\text { Percent }\end{array}$ & 0,8 & 3,9 & 5,1 & 12,4 & 16,6 & 16,6 & 76,9 & 93,6 & 99,4 & 100 & 100 & 100 \\
\hline Total & & & & & & & & & & & & 373 \\
\hline
\end{tabular}


The highest result ( $60 \%$ of the respondents) was received by the variant "improvement of living conditions (creation of work places, salary increase, housing available)" and "improvement of the image of the country (increasing Latvia's role significance on the international level)", which was chosen by $17 \%$ of the respondents.

In the next unit, the objects are the individual, personal qualities of the patriot/ the antipatriot as well as an individual's actions (activity), which can be helpful for the Motherland. The main question was "Are you a patriot of Latvia?", and $64 \%$ of the respondents gave a positive reply, $25 \%$ answered "It's difficult to say", 5\% replied negatively and 6\% answered that they have not thought about it. If we summarise the answers, we will see that teenagers think that a patriot's personal qualities are the following: "a person, who loves and respects his country", "respecting, honouring, taking care of the family, nature, people", "a person voting at elections in his country", "a person, who can criticise drawbacks in his country, defend his point of view, who is not indifferent", "a person, who is proud of his country", "a person, who is ready to defend his home, land, to sacrifice his life for freedom of the Motherland".

Antipatriot's personal qualities: "a person hating his country", "a person who does not respect the people of this country, neglecting traditions and history", "a person, who does not know the anthem of his country", "a person, who is indifferent to his country".

\section{Table 7.}

Are you a patriot of Latvia?

$\begin{array}{ccccc}\text { Frequency } & \text { Percent } & \begin{array}{c}\text { Valid } \\ \text { Percent }\end{array} & \begin{array}{c}\text { Cumulative } \\ \text { Percent }\end{array} \\ \text { Valid Yes } & 239 & 63,8 & 63,8 & 63,8 \\ \text { No } & 19 & 5,3 & 69,1 & 69,1 \\ \text { It's difficult to say } & 93 & 25,1 & 94,2 & 94,2 \\ \text { I haven't thought } & 22 & 5,8 & 100 & 100 \\ \begin{array}{c}\text { about it } \\ \text { Total }\end{array} & 373 & 100 & 100 & \end{array}$

Source: Author`s research

When asked the question "What is necessary for motivating a person to act for the sake of his Motherland?", the respondents gave such answers: a little bit more than a half of them (54\%) think that the main motivation is education: "study well in order to become useful for the Motherland", 19\% of the respondents believe that it will be sufficient to "simply love and respect the native country". There is an interesting fact: almost the same numbers of respondents (18\%) say that in order to motivate for beneficial actions for the state it is necessary "to ensure material stimulation", which proves the significance of material values for teenagers. 
Table 8.

Activities for motivation a person to act for the sake of his Motherland

No. What is necessary for motivating a person to act for the sake of his Motherland?

1 conversations and talks with friends on patriotic topics; 0

2 study well in order to become useful for the Motherland; 52

$\begin{array}{lll}3 & \text { take part in work of patriotic organisations; } & 7\end{array}$

4 organise thematic patriotic events; 4

5 to ensure material stimulation; $\quad \mathbf{1 8}$

6 watching patriotic films; 0

7 simply love and respect your country; $\quad 19$

8 other.

What is necessary for motivating a person to act for the Total sake of his Motherland?

$\begin{array}{cccccccccc} & \mathbf{1 .} & \mathbf{2 .} & \mathbf{3 .} & \mathbf{4 .} & \mathbf{5 .} & \mathbf{6 .} & \mathbf{7 .} & \mathbf{8 .} & \\ \text { Frequency } & 0 & 194 & 26 & 15 & 67 & 0 & 71 & 0 & \mathbf{3 7 3} \\ \text { Percent } & 0 & 52,1 & 6,7 & 4,3 & 18,1 & 0 & 18,8 & 0 & \mathbf{1 0 0} \\ \text { Valid Percent } & 0 & 52,1 & 6,7 & 4,3 & 18,1 & 0 & 18,8 & 0 & \mathbf{1 0 0} \\ \text { Cumulative } & 0 & 52,1 & 58,8 & 63,1 & 81,2 & 81,2 & 100 & 100 & \mathbf{1 0 0} \\ \quad \begin{array}{l}\text { Percent } \\ \text { Total }\end{array} & & & & & & & & & \\ \text { Source: Author's research } & & & & & & & & \mathbf{3 7 3}\end{array}$

\section{CONCLUSIONS}

The theoretical analysis makes it possible to conclude that the main idea of the concept patriotism consists of considering it as one of the highest values of the individual and is the basis of life orientations, defining the strategy of the individual's development, harmonisation of the society and the state. The main approaches for investigation of the concept of patriotism are: sensitively emotional, active and publically national.

The empirical research showed that Latvian teenagers have rather a precise understanding of the concept of patriotism. Thus, the teenagers define the concept as love for the Motherland, love of the family, relatives. The following definition prevails: "Patriotism is a moral and political principle, a social sense, consisting of love for the Motherland, pride for its past and present, readiness to subordinate own interests to interests of the state". An interesting aspect should be mentioned: under conditions of globalisation, polyculture and integration processes in the modern society the teenagers do not relate this concept with "communal way of life", "aspiration for safe global peace", "separating oneself and own state from other states and nations". It should be noted that rather a large number of respondents believe that "under conditions of globalisation patriotism is losing its meaning". 
It is important to state that more than a half of teenagers in Latvia are "proud of their country". But there is a hidden warning in the fact that there is rather a large number of respondents who "do not feel any pride for their country" and the fact that almost one third of the respondents are ready "to emigrate from the country", and it is gradually happening in Latvia today.

In the respondents' opinion, the main conditions for development of patriotic values are "improvement of living conditions (creation of work places, salary increase, housing available)" and "improvement of the image of the country (increasing Latvia's role significance on the international level)".

The largest part of the respondents states their belonging to the country and thinks that they are patriots, and only a few respondents do not feel as patriots of Latvia. The following fact is also worrying: rather a large number of the respondents - almost half of them - could not answer that important question.

"Study well in order to become useful for the Motherland" is considered to be the principal activity for the benefit of the native country. It can be remarked that almost one fifth of the respondents believe that it is necessary "to ensure material stimulation" to motivate active behaviour for the sake of the country, thus proving the significance of material values for teenagers.

\section{REFERENCE}

[1] Āboltina, S. (2014). Izglìtības attīstības pamatnostādes 2014.-2020.gadam Latvijā [Guidelines for the Development of Education for 2014-2020 in Latvia]. Rīga: Latvijas Vēstnesis.

[2] Aristotle. (2009). Politics. Oxford: Oxford World`s Classics.

[3] Basov, N., Basova, V., \& Kravcenko, A. (2018). Istorija socialjnih nauk [History of Social Sciences]. Moskva: JURAIT

[4] Berger, B. (2011). Attention Deficit Democracy: The Paradox of Civic Engagement. Princeton: Princeton University Press.

[5] Berzinš̌, A. (2014). Grozījums Latvijas Republikas Satversmē [Amendment to the Constitution of the Republic of Latvia]. Rīga: Latvijas Vēstnesis.

[6] Butulis, I. (2012). Kas ir patriotisms? [What is patriotism?]. Retrieved from: https://www.lsm. lv/raksts/zinas/latvija/kas-ir-patriotisms.a24089/.

[7] Commission of the European communities. (2009). An EU Strategy for Youth - Investing and Empowering. Retrieved from: http:/ / aei.pitt.edu/42318/1/com2009_0200.pdf.

[8] Dombrovskis, V. (2012). Latvijas Nacionālais attīstibas plāns 2014.-2020.gadam [The National Development plan of Latvia for 2014-2020]. Rīga: Pārresoru koordinācijas centrs.

[9] Ēltere, S. (2011). Par Nacionālās identitātes, pilsoniskās sabiedrības un integrācijas politikas pamatnostādnèm 2012.-2018.gadam [On National Identity, Civil Society and Integration Policy Guidelines 2012-2018]. Rīga: Latvijas Vēstnesis.

[10] Izard, C. (2013). The Psychology of Emotions. New York: Plenum.

[11] Konfucij. (2014). Samiji ostroumnije aforizmi $i$ citati [The most witty aphorisms and quotes]. Moskva: AST.

[12] Kont-Sponvilj, A. (2012). Filisofskij slovarj [Philosophical dictionary]. Moskva: AST.

[13] Kurginjan, M. (1958). Dzordz Bajron: Kritiko-biograficheskij ocherk [George Byron: A Curriculum Vitae]. Moskva: Goslitizdat.

[14] Marchenoka, M. (2016). Responsibility in the hierarchical system of teenagers'values in Latvia. Journal Association 1901 „SEPIKE” (Social Educational Project of Improving Knowledge in Economics), Edition 14, 23-28.

[15] Montesquieu, Ch. (2008). The Spirit of Laws. Complete Works, vol.1. Oxford: Oxford Univer- 
sity Press.

[16] Platon. (2016). Gosudrstvo [State]. Moskva: ACT.

[17] Platon. (2007). Sochinenija v chetirjeh tomah [Works in four volumes]. T. 3. Ч. 1. izdateljstvo S. Peterburgskogo universiteta.

[18] Susan Muaddi Darraj. (2010). The Universal Declaration of Human Rights (Milestones in modern world history). Chelsea House: Infobase Publishing.

[19] Tomas, M. (2013). Inaguracija ot Vashingtona do Obami [Inauguration from Washington to Obama]. Retrieved from: http://inosmi.ru/usa/20130120/204835087-print.html, Retrieved from https://cyberleninka.ru/article/v/patriotizm-i-grazhdanskiy-natsionalizm-v-soznanii-studenchestva .

[20] UNICEF. (2012). Progress for children. United Nations Children's Fund, New York. Retrieved from: http://www.unicef.org/media/files/PFC2012_A_report_card_on_adolescents.pdf. 